\title{
Role of Lipid Rafts in Hematopoietic Stem Cells Homing, Mobilization, Hibernation, and Differentiation
}

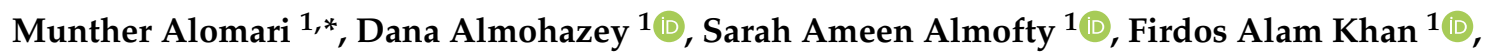 \\ Mohammad Al hamad ${ }^{2}$ and Deena Ababneh ${ }^{3}$ \\ 1 Department of Stem Cell Biology, Institute for Research and Medical Consultations, \\ Imam Abdulrahman Bin Faisal University, Post Box No. 1982, Dammam 31441, Saudi Arabia; \\ daaalmohazey@iau.edu.sa (D.A.); saalmofty@iau.edu.sa (S.A.A.); fakhan@iau.edu.sa (F.A.K.) \\ 2 Department of Pathology, College of Medicine, Imam Abdulrahman Bin Faisal University, \\ Post Box No. 1982, Dammam 31441, Saudi Arabia; mhamad@iau.edu.sa \\ 3 Department of Basic Sciences and Humanities, College of Engineering, \\ Imam Abdulrahman Bin Faisal University, Post Box No. 1982, Dammam 31441, Saudi Arabia; \\ dababneh@iau.edu.sa \\ * Correspondence: maomari@iau.edu.sa; Tel.: +966-1333-30866
}

Received: 2 May 2019; Accepted: 14 June 2019; Published: 22 June 2019

check for updates

\begin{abstract}
Hematopoietic stem cells (HSCs) are multipotent, self-renewing cells that can differentiate into myeloid or lymphoid cells. The mobilization and differentiation processes are affected by the external environment, such as extracellular matrix and soluble molecules in the niche, where the lipid rafts (LRs) of the HSCs act as the receptors and control platforms for these effectors. LRs are membrane microdomains that are enriched in cholesterol, sphingolipid, and proteins. They are involved in diverse cellular processes including morphogenesis, cytokinesis, signaling, endocytic events, and response to the environment. They are also involved in different types of diseases, such as cancer, Alzheimer's, and prion disease. LR clustering and disruption contribute directly to the differentiation, homing, hibernation, or mobilization of HSCs. Thus, characterization of LR integrity may provide a promising approach to controlling the fate of stem cells for clinical applications. In this review, we show the critical role of LR modification (clustering, disruption, protein incorporation, and signal responding) in deciding the fate of HSCs, under the effect of soluble cytokines such as stem cell factor (SCF), transforming growth factor- $\beta$ (TGF- $\beta$ ), hematopoietic-specific phospholipase $\mathrm{C} \beta 2$ (PLC- $\beta 2)$, and granulocyte colony-stimulating factor (G-CSF).
\end{abstract}

Keywords: LRs; HSCs; differentiation; homing; hibernation; mobilization; SCF; TGF- $\beta$; PLC- $\beta 2$; G-CSF

\section{Introduction}

Lipid rafts (LRs) were characterized as functional domains at the plasma membrane more than 30 years ago [1]. Although the existence and biological function of LRs remained controversial for many years, the analysis of their structure and function is currently at the leading edge of biomembrane and cell biology investigations [2,3]. LRs are specialized microdomains (10-200 nm) located in the plasma membrane [3], highly heterogeneous and enriched with sphingolipid (sphingomyelin), sterol, cholesterol, and protein [4-8]. The structure and saturated hydrocarbon chain of sphingolipids allow preferential interaction with cholesterol. In addition, saturated fatty acids and cholesterol can pack tightly, forming a thick and rigid raft area at the cell surface $[9,10]$. In contrast, the plasma membrane is mainly composed of unsaturated fatty acids and lipids, making it loosely packed and 
more fluid [11]. The modification of some types of proteins, such as src family kinases and proteins with GPI (glycosylphosphatidylinositol) anchors by fatty acid addition, allows them to associate with LRs [12,13]. LRs are dynamic structures which are able to move through the plasma membrane, collapsing into tiny domains or clustering to form a large platform. They play an interesting role in numerous cellular activities, such as endocytic and secretory pathways [14]. In addition, LRs facilitate cell signaling in B- $[15,16]$ and T-cells $[6,17,18]$. Several cell surface antigens are either located in, or move into, LRs to be functional [19,20]. For example, the colocalization of the B-cell receptor and CD5 in LRs is necessary to induce the early signaling pathway that leads to apoptosis [21].

Proteins are recruited into LRs as a result of several stimuli (e.g., therapeutic antibodies [22], radiation [23], and hormones [24]). This incorporation is facilitated by a GPI anchor or acylation of these proteins [25]. LRs act as cellular portals that link the exogenous environment to the endocytic pathways and enable the internalization of toxins [26] and viral particles [27]. The allocation of LRs at the cell membrane relies upon cell type. For example, in B- lymphocytes, LRs are accumulated in microvilli-rich regions [28].

LRs are involved in cell membrane trafficking including membrane budding, polarization, invadopodia, and release of exosomes [29,30]. In addition, they have been involved in various diseases, for example, cancer, prion diseases, and Alzheimer's [31]. The dysregulation of LR proteins results in subsequent effects on signaling and tumor progression. For example, depletion of cholesterol disturbs $\mathrm{LR}$ association with prion protein, $\mathrm{PrP} \mathrm{P}^{\mathrm{C}}$, and stops $\mathrm{PrP}^{\mathrm{Sc}}$ conversion. In addition, reorganization of LR cholesterol decreases A $\beta$ formation in Alzheimer's [32]. This membrane domain also is an important binding site for therapeutic antibodies, for example, anti-CD20 (Rituximab) used to treat CLL patients [33]. In addition, several anticancer drugs have been shown to suppress growth and induce apoptosis of tumor cells through LR remodeling, such as Edelfosine [34], avicin D [35], resveratrol [36], and liver $X$ receptors [37]. Raft microdomains provide a signaling pathway platform capable of various cellular pro- and antiapoptotic pathways that may be initiated upon LR distribution [38,39]. Indeed, many receptor tyrosine kinases are localized in LRs [6,40-43], highlighting the importance of this membrane microdomain in cell signaling. Furthermore, the modulation of cholesterol levels in acute myeloid leukemia (AML) cells kills and sensitizes them to therapeutic drugs [38,39].

LRs play an important role in hematopoietic stem cells (HSCs) differentiation, homing, and mobilization. HSCs are multipotent, rare, and self-renewing cells that can be found in the bone marrow, umbilical cord blood, and peripheral blood. Most are quiescent at any given time (G0). HSCs were first identified in the dorsal aorta and urogenital ridges (UGR) and characterized with

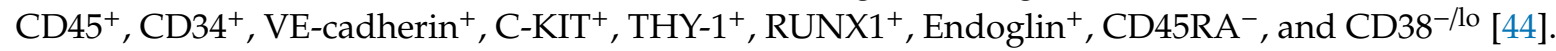
During embryogenesis, HSCs are located in the yolk sac, and then they migrate to the bone marrow, liver, and spleen [45]. HSCs differentiate into all functional types of blood cells of lymphoid and myeloid lineages [46] (Figure 1) and maintain multilineage hematopoiesis throughout the entire lifespan $[47,48]$. Hematopoiesis or clinical transplantation requires successful mobilization, homing, and differentiation processes of HSCs. Many factors play a role in these processes; here, we focus on the role of LRs. 


\section{Hematopoiesis}

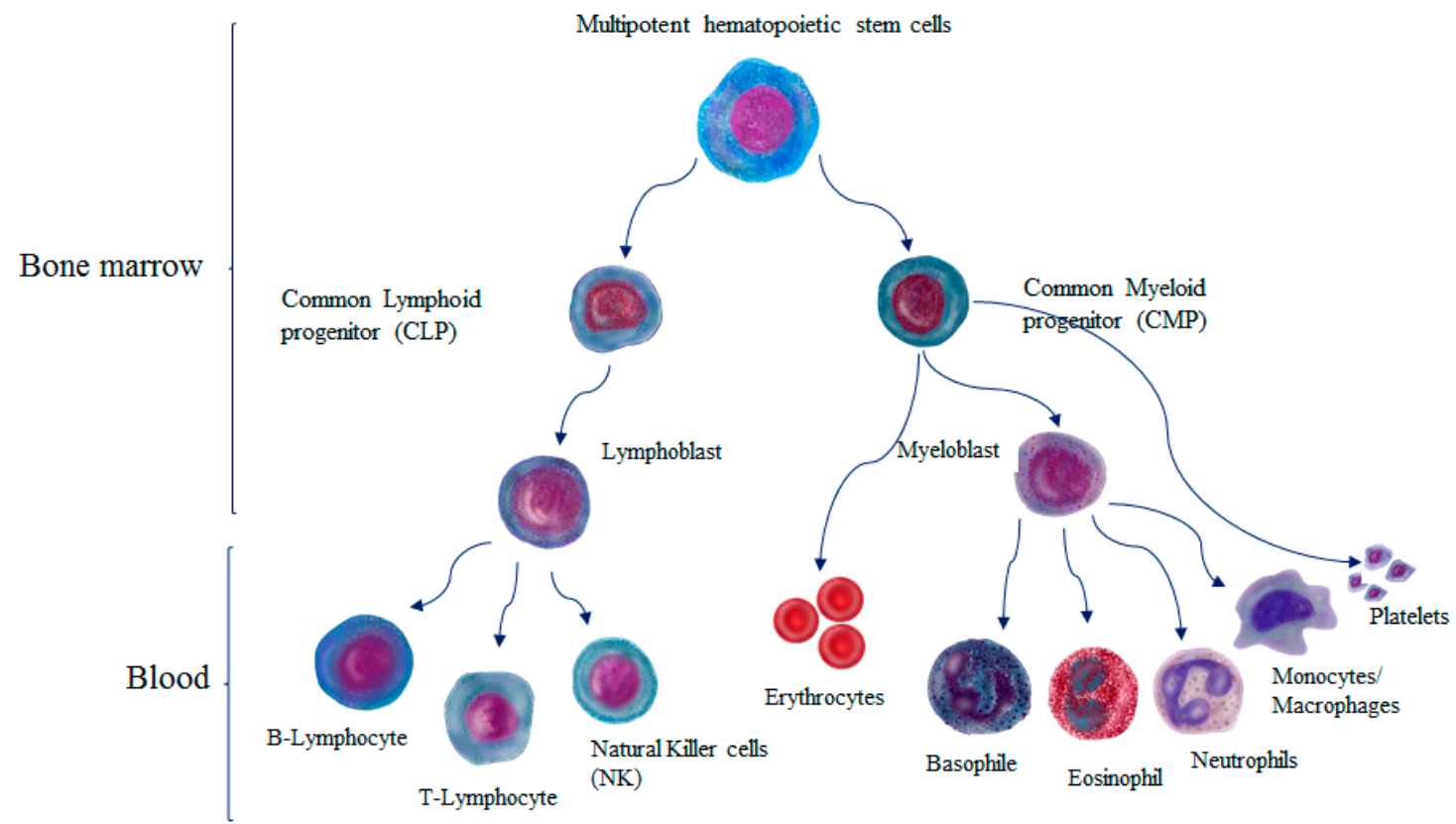

Figure 1. Hematopoiesis process. This process leads to the formation of highly specialized circulating blood cells from HSCs in the bone marrow (BM). Multipotent hematopoietic stem cells in BM differentiate into myeloid or lymphoid progenitor cells. Myeloid cells differentiate into red blood cells, platelets, and myeloblasts, which differentiate into basophils, neutrophils, eosinophils, and macrophages, while lymphoid cells differentiate into B and T-lymphocytes and natural killer cells (NK).

\section{HSC Mobilization and Homing}

HSCs are located in a specialized place in the niche of bone marrow, with stromal cells, extracellular matrix (ECM), and soluble factors such as cytokines, that control the fate of stem cells [49]. ECM molecules, such as fibronectin, laminin, and collagen, can influence adhesion, maintenance, proliferation, migration, and differentiation of stem cells [50,51]. Interactions between fibronectin and HSCs are mediated through integrins at the cell surface for cell adhesion function [52]. In addition, integrins serve as major receptors for ECM proteins and are capable of mediating bidirectional signal transduction across the plasma membrane [53]. For example, in adherent cells, integrins target Rac protein to the plasma membrane and couple it to the downstream effector, p21-activated kinase, to activate the downstream signaling pathway [54,55]. For integrins to perform the interaction with fibronectin, Rac must be targeted to, and activated by, LRs [56,57]. The disruption of LRs results in prevention of cell adhesion and targeting of Rac to the plasma membrane [58].

LR structure on the surface of the cell membrane helps the association of signaling molecules such as Rac-1, Lyn, and RhoH, with the LR-associated surface receptors CXCR4, $\alpha 1 \beta 4$ integrin (VLA-4), and CD 117. This results in regulation of the migration, mobilization, and homing of HSCs. VLA-4 and CXCR4 are LR-associated proteins that bind to ligands VCAM-1 and SDF-1, respectively. These ligands are expressed within the niche environment of stem cells and are consequently involved in anchoring the HSCs to the niches [59-62]. At the mobilization stage, PLC- $\beta 2$ is expressed by neutrophils in response to premobilization factors such as AMD3100, sphingosine 1-phosphate (S1P), G-CSF, and C5a. PLC- $\beta 2$ cleaves glycolipid glycosylphosphatidylinositol anchor (GPI-A), which is necessary for LR integrity, partitioning, signal transduction, and cellular communication. Cleavage of GPI-A results in the disruption of LR and associated proteins VLA-4 and CXCR4, leading to the detachment of SDF- 1 and VCAM- 1 ligands and hence to HSC mobilization. Also, PLC- $\beta 2$ removes VCAM- 1, CD59, and CD55 from the cell membrane, resulting in activation of the mobilization-promoting complement 
cascade $[59,63]$, as shown in Figure 2. On the other hand, exposure of HSCs to heat treatment (39.5 ${ }^{\circ} \mathrm{C}$ ) leads to the incorporation of CXCR4 into functional LRs with Rac1, which subsequently enhances HSCs homing and engraftment [64].

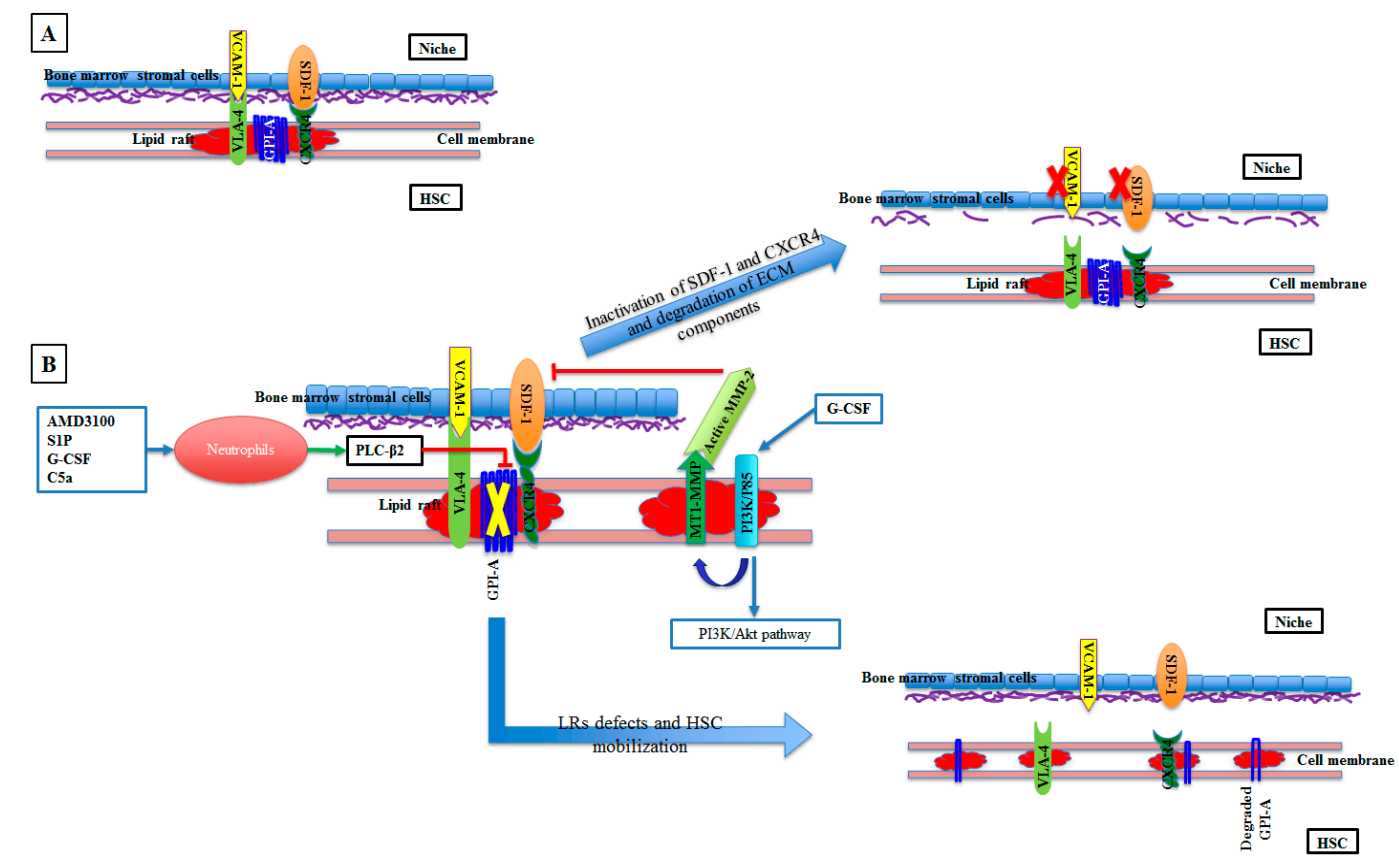

Figure 2. Role of LRs in HSC mobilization. A, Quiescent status of HSC in the niche: The LR incorporated proteins VAL-4 and CXCR4 of HSCs bind to VCAM-1 and SDF-1 proteins of the niche, resulting in HSC stabilization. B, Mobilization status of HSCs: premobilization factors found in the niche, such as AMD3100, S1P, G-CSF, and C5a, enhance the expression of PLC- $\beta 2$ of neutrophils. PLC- $\beta 2$ cleaves GPI-A in the LRs, resulting in disruption of LRs and associated proteins VLA-4 and CXCR4, leading to the detachment of SDF-1 and VCAM-1 ligands and HSC mobilization. In addition, G-CSF activates PI3K/P85 located in the LRs of HSCs, leading to activation of the PI3K/Akt pathway and incorporation of MT1-MMP into the LR, activating MMP-2 at the cell surface. MMP-2 then modulates the matrix, inactivating SDF-1 and CXCR4 and enhancing pericellular degradation of the ECM components. These changes result in the release of HSCs from the bone marrow niches.

Successful HSC transplantation requires modulation processes such as mobilization and homing, which are controlled by membrane type 1 metalloprotease (MT1-MMP). The presentation of MT1-MMP on the HSCs' surface is regulated by LRs incorporation [65]. Cytokines such as G-CSF activate PI3K in LRs, leading to the activation of the PI3K/Akt pathway, MT1-MMP embodiment in LRs, and pro-MMP-2 activation. Active MMP-2 modulates the matrix, inactivating SDF-1 and CXCR4 [66] and enhancing pericellular degradation of ECM components such as fibronectin, gelatin, vitronectin, fibrillar collagens, and laminin [67]. These changes result in the release of HSCs of the bone marrow niches across subendothelial membranes and ECM [66] (Figure 2). Accordingly, the incorporation of MT1-MMP in LRs is critical to the HSCs' mobilization. On the other hand, the disruption of LRs by M $\beta C D$ or statin inhibits the inclusion of MT1-MMP into LRs, resulting in immobilized HSCs [66].

\section{HSC Differentiation}

The process of HSC differentiation is an important issue, and revealing its mechanism might open up new avenues for therapeutic strategies. Hematopoietic stem cells rest in hibernation mode in bone marrow niches $[68,69]$. Occasionally, the HSCs enter the cell cycle after cytokines activation. The fate of these stem cells is determined by secreted molecules or by signals through the cell surface. HSCs in bone marrow niches lack LR clustering and show inactive serine/threonine kinase AKT, 
abundant p57 Kip2 cyclin-dependent kinase inhibitor, and nuclear localization of FOXO transcription factors (FOXO1, FOXO3, FOXO4, and FOXO6) [70]. Activation of LR clustering by SCF incorporates receptor tyrosine kinase c-Kit (CD 117) in LR clusters and stimulates the PI3K-Akt-FOXO pathway, which induces HSC activation and cell cycling [71]. On the other hand, the inhibition of LR clustering and induction of $\mathrm{p} 57^{\mathrm{Kip} 2}$ expression by TGF- $\beta$ induces HSC hibernation. In addition, inhibition of LR clustering by methyl- $\beta$-cyclodextrin $(\mathrm{M} \beta \mathrm{CD})$ shows inhibition of AKT downstream activity and nuclear localization of FOXO and thus inhibition of HSC proliferation. These findings highlight the importance of LRs in HSC fate [70,72,73] (Figure 3).
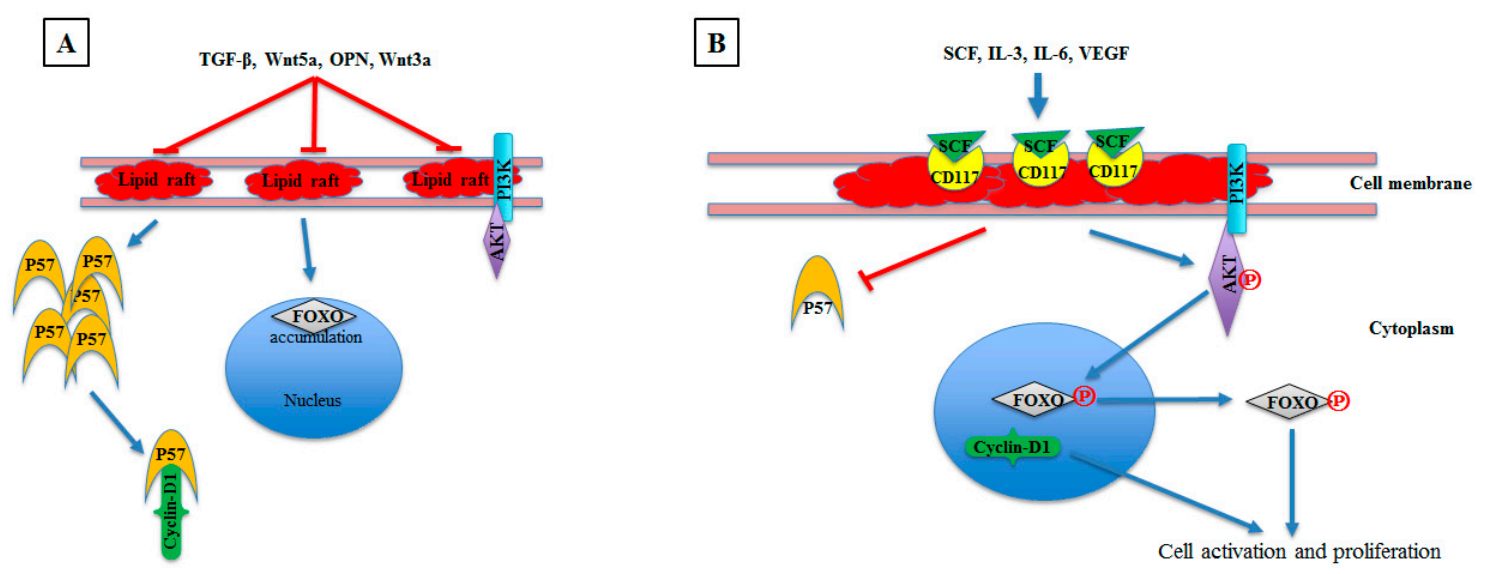

Figure 3. Role of LRs in HSC differentiation. A, HSCs rest in hibernation mode in bone marrow niche under the effect of Wnt5a, OPN, Wnt3a, or TGF- $\beta$ cytokines. These cytokines decrease LRs clustering, show inactive AKT, abundant $\mathrm{p} 57^{\mathrm{Kip} 2}$, and nuclear localization of FOXO transcription factors. Abundant $\mathrm{p} 57^{\mathrm{Kip} 2}$ binds Cyclin-D1, resulting in inhibition of cell proliferation. B, Activation of LR clustering by SCF or IL-3 or IL-6 or VEGF leads to incorporation of CD 117 in the LR cluster, resulting in simulation of the PI3K-Akt-FOXO pathway. Active AKT $\mathrm{P}$ phosphorylates FOXO, resulting in translocation of FOXO from the nucleus to the cytoplasm and initiation of HSC cell cycling. LR clustering and CD117 incorporation also reduce P57 abundance, thus increasing Cyclin-D1 translocation into the nucleus with additional initiation of HSC proliferation.

The LR status of clustering or diffusion could therefore be an indicator of HSC activation or inhibition, respectively. Other proteins have also been shown to contribute to LR clustering or diffusion and thus to HSC activation or hibernation. For example, Wnt5a, OPN, Wnt3a, and TGF- $\beta$ decrease LR clustering and cell cycling, whereas IL-3, IL-6, and VEGF activate LR clustering, resulting in CD 117 colocalization with LRs, indicating HSC activation through the PI3K-Akt pathway $[71,74,75]$ (Figure 3).

Prominin-1 (CD133), a membrane glycoprotein associated with LR-membrane vesicles [76], has been identified as a marker of neuronal cells [77], immature hematopoietic stem cells [78,79], and cancer stem cells [80]. CD133 is located in the finger-like projections of the cell membrane of HSCs, where it can bind to cholesterol-containing LRs and is involved in various signaling functions [81,82]. It is also associated with released membrane vesicles in body fluids [76]. CD133 is an important physiological regulator of stem cell expansion and maintenance and has been linked to stem cell fate decisions $[83,84]$. During the process of differentiation, hematopoietic stem and progenitor cells (HSPCs) release CD133-containing membrane vesicles (CD133-CMV), which are then internalized by feeder cells. These data showed that the CD133-containing LRs may host critical roles in maintaining stem cell properties and their loss or reduction may cause cellular differentiation [85].

The liver $X$ receptors (LXRs) are cholesterol-sensing nuclear receptors which are activated by oxidized derivatives of cholesterol (oxysterols). LXRs induce expression of cholesterol efflux transporter APOE and Abcg1, thus inhibiting cholesterol absorption [86-88]. Cholesterol efflux takes place at the cell membrane through LRs [89]. Therefore, expression of APOE and Abca1/g1 in HSCs interrupts membrane LRs, resulting in inhibition of HSC proliferation and differentiation to myeloid cells. On the 
other hand, APOE and Abca1/g1 knockout mice show upregulation of membrane cholesterol and LR formation that results in HSC monocytosis [90,91]. Thus, LXR modulates LR integrity, which affects the fate of HSCs.

LRs have been described in many different cell types, including HSCs, to be the platforms for signaling molecules implicated in the management of cell differentiation. LRs have been investigated for their involvement in the blockage of neutrophil differentiation during Clostridium perfringens infection. The LR marker GM1 ganglioside was found to be reduced with neutrophil differentiation and increased with $\alpha$-toxin (from Clostridium perfringens type A) treatment of bone marrow cells. Also, infection of Clostridium perfringens type A increased the GM1 expression at cell surface of myeloid cells. These data were confirmed by disruption of LRs by M $\beta C D$ that resulted in the blockage of neutrophil differentiation [92], indicating direct involvement of LR content and integrity in neutrophil fate.

The effect of vesicles on the fate of HSCs is commonly discussed in many research papers, indicating the major role of these vesicles in HSC differentiation. The entry of extracellular vesicles is mediated through LRs. For example, megakaryocytic microparticles, small membrane vesicles derived by budding from the cell membrane of megakaryocytes, can fuse into the cell membrane or get endocytosed into hematopoietic and progenitor stem cells through micropinocytosis and LRs. This process results in the differentiation of HSPCs into megakaryocytes, indicating the coordinated role of LRs and extracellular vesicles on HSC differentiation [93].

\section{Summary}

LRs are membrane platforms that regulate cell signaling and differentiation through protein-protein and protein-lipid interactions in hematopoietic stem cells. LR clustering or interruption is the main effector on HSCs differentiation, mobilization, and hibernation. The activation of LR clustering by SCF, IL-3, IL-6, and VEGF initiates HSC activation, while the inhibition of LR clustering by Wnt5a, OPN, Wnt3a, and TGF- $\beta$ results in HSC hibernation. LXRs interrupt LR integrity, resulting in inhibition of HSC differentiation. However, CD133-containing LRs may be responsible for the maintenance of HSC properties and their loss may result in differentiation. On the other hand, endocytosis of extracellular vesicles through LRs enhances HSC-specific differentiation. For example, the internalization of megakaryocytic microparticles through LRs into HSPCs results in the differentiation of HSPCs into megakaryocytes. LRs are also involved in HSC mobilization. For example, disruption of LRs by PLC- $\beta 2$ in ECM results in HSC mobilization. In addition, incorporation of MT1-MMP into LRs, which enhances the degradation of the connection between HSCs and ECM, results in the release of HSCs.

Author Contributions: M.A. took the lead in writing the manuscript and wrote the introduction and summary and designed the graphical abstract. D.A. wrote the differentiation section. S.A.A. and F.A.K. wrote the mobilization and homing section. D.A. and M.A.h. designed the graphs. All authors provided critical feedback and helped shape the review.

Acknowledgments: The authors are thankful to the entire management of the Institute for Research and Medical Consultations (IMRC), Imam Abdulrahman Bin Faisal University, Dammam, Kingdom of Saudi Arabia, for their support and encouragement.

Conflicts of Interest: The authors have declared no conflict of interest.

\section{References}

1. Simons, K.; Van Meer, G. Lipid sorting in epithelial cells. Biochemistry 1988, 27, 6197-6202. [CrossRef] [PubMed]

2. Bodin, S.; Soulet, C.; Tronchere, H.; Sie, P.; Gachet, C.; Plantavid, M.; Payrastre, B. Integrin-dependent interaction of lipid rafts with the actin cytoskeleton in activated human platelets. J. Cell Sci. 2005, 118, 759-769. [CrossRef] [PubMed]

3. Varma, R.; Mayor, S. GPI-anchored proteins are organized in submicron domains at the cell surface. Nature 1998, 394, 798-801. [CrossRef] [PubMed] 
4. Pike, L.J. Rafts defined: A report on the Keystone Symposium on Lipid Rafts and Cell Function. J. Lipid Res. 2006, 47, 1597-1598. [CrossRef] [PubMed]

5. Rajendran, L.; Simons, K. Lipid rafts and membrane dynamics. J. Cell Sci. 2005, 118, 1099-1102. [CrossRef] [PubMed]

6. Simons, K.; Toomre, D. Lipid rafts and signal transduction. Nat. Rev. Mol. Cell Biol. 2000, 1, 31-39. [CrossRef] [PubMed]

7. Simons, K.; Vaz, W.L. Model systems, lipid rafts, and cell membranes. Annu. Rev. Biophys. Biomol. Struct. 2004, 33, 269-295. [CrossRef]

8. Pike, L.J. Lipid rafts: Heterogeneity on the high seas. Biochem. J. 2004, 378, 281-292. [CrossRef]

9. Pike, L.J. The challenge of lipid rafts. J. Lipid Res. 2009, 50, S323-S328. [CrossRef]

10. Korade, Z.; Kenworthy, A.K. Lipid rafts, cholesterol, and the brain. Neuropharmacology 2008, 55, 1265-1273. [CrossRef]

11. Dharani, K. Chapter 7-Molecular-Grid Model. In The Biology of Thought; Dharani, K., Ed.; Academic Press: San Diego, CA, USA, 2015; pp. 123-142. [CrossRef]

12. Oh, P.; Schnitzer, J.E. Segregation of heterotrimeric G proteins in cell surface microdomains. G(q) binds caveolin to concentrate in caveolae, whereas G(i) and G(s) target lipid rafts by default. Mol. Biol. Cell 2001, 12, 685-698. [CrossRef] [PubMed]

13. Pike, L.J. Lipid rafts: Bringing order to chaos. J. Lipid Res. 2003, 44, 655-667. [CrossRef] [PubMed]

14. Nabi, I.R.; Le, P.U. Caveolae/raft-dependent endocytosis. J. Cell Biol. 2003, 161, 673-677. [CrossRef] [PubMed]

15. Cheng, P.C.; Cherukuri, A.; Dykstra, M.; Malapati, S.; Sproul, T.; Chen, M.R.; Pierce, S.K. Floating the raft hypothesis: The roles of lipid rafts in B cell antigen receptor function. Semin. Immunol. 2001, 13, 107-114. [CrossRef] [PubMed]

16. Pierce, S.K. Lipid rafts and B-cell activation. Nat. Rev. Immunol. 2002, 2, 96-105. [CrossRef] [PubMed]

17. Brown, D.A.; London, E. Structure and function of sphingolipid- and cholesterol-rich membrane rafts. J. Biol. Chem. 2000, 275, 17221-17224. [CrossRef] [PubMed]

18. Dykstra, M.; Cherukuri, A.; Sohn, H.W.; Tzeng, S.J.; Pierce, S.K. Location is everything: Lipid rafts and immune cell signaling. Annu. Rev. Immunol. 2003, 21, 457-481. [CrossRef]

19. Cahuzac, N.; Baum, W.; Kirkin, V.; Conchonaud, F.; Wawrezinieck, L.; Marguet, D.; Janssen, O.; Zörnig, M.; Hueber, A.O. Fas ligand is localized to membrane rafts, where it displays increased cell death-inducing activity. Blood 2006, 107, 2384-2391. [CrossRef]

20. Varshney, P.; Yadav, V.; Saini, N. Lipid rafts in immune signalling: Current progress and future perspective. Immunology 2016, 149, 13-24. [CrossRef]

21. Perez-Chacon, G.; Vargas, J.A.; Jorda, J.; Alvarez, N.; Martin-Donaire, T.; Rosado, S.; Losada-Fernandez, I.; Rebolleda, N.; Perez-Aciego, P. CD5 does not regulate the signaling triggered through BCR in B cells from a subset of B-CLL patients. Leuk. Lymphoma 2007, 48, 147-157. [CrossRef]

22. Cragg, M.S.; Morgan, S.M.; Chan, H.T.; Morgan, B.P.; Filatov, A.V.; Johnson, P.W.; French, R.R.; Glennie, M.J. Complement-mediated lysis by anti-CD20 mAb correlates with segregation into lipid rafts. Blood 2003, 101, 1045-1052. [CrossRef] [PubMed]

23. Lucero, H.; Gae, D.; Taccioli, G.E. Novel localization of the DNA-PK complex in lipid rafts: A putative role in the signal transduction pathway of the ionizing radiation response. J. Biol. Chem. 2003, 278, 22136-22143. [CrossRef] [PubMed]

24. Baumann, C.A.; Ribon, V.; Kanzaki, M.; Thurmond, D.C.; Mora, S.; Shigematsu, S.; Bickel, P.E.; Pessin, J.E.; Saltiel, A.R. CAP defines a second signalling pathway required for insulin-stimulated glucose transport. Nature 2000, 407, 202-207. [CrossRef] [PubMed]

25. Lucero, H.A.; Robbins, P.W. Lipid rafts-protein association and the regulation of protein activity. Arch. Biochem. Biophys. 2004, 426, 208-224. [CrossRef] [PubMed]

26. Tran, D.; Carpentier, J.L.; Sawano, F.; Gorden, P.; Orci, L. Ligands internalized through coated or noncoated invaginations follow a common intracellular pathway. Proc. Natl. Acad. Sci. USA 1987, 84, 7957-7961. [CrossRef] [PubMed]

27. Stang, E.; Kartenbeck, J.; Parton, R.G. Major histocompatibility complex class I molecules mediate association of SV40 with caveolae. Mol. Biol. Cell 1997, 8, 47-57. [CrossRef] [PubMed] 
28. Greicius, G.; Westerberg, L.; Davey, E.J.; Buentke, E.; Scheynius, A.; Thyberg, J.; Severinson, E. Microvilli structures on B lymphocytes: Inducible functional domains? Int. Immunol. 2004, 16, 353-364. [CrossRef] [PubMed]

29. Yamaguchi, H.; Oikawa, T. Membrane lipids in invadopodia and podosomes: Key structures for cancer invasion and metastasis. Oncotarget 2010, 1, 320-328. [CrossRef]

30. Nicolson, G.L. Cell Membrane Fluid-Mosaic Structure and Cancer Metastasis. Cancer Res. 2015, 75, 1169-1176. [CrossRef]

31. Staubach, S.; Hanisch, F.G. Lipid rafts: Signaling and sorting platforms of cells and their roles in cancer. Expert Rev. Proteom. 2011, 8, 263-277. [CrossRef]

32. Hannaoui, S.; Shim, S.Y.; Cheng, Y.C.; Corda, E.; Gilch, S. Cholesterol Balance in Prion Diseases and Alzheimer's Disease. Viruses 2014, 6, 4505-4535. [CrossRef] [PubMed]

33. Janas, E.; Priest, R.; Wilde, J.I.; White, J.H.; Malhotra, R. Rituxan (anti-CD20 antibody)-induced translocation of CD20 into lipid rafts is crucial for calcium influx and apoptosis. Clin. Exp. Immunol. 2005, 139, 439-446. [CrossRef] [PubMed]

34. Gajate, C.; Mollinedo, F. Edelfosine and perifosine induce selective apoptosis in multiple myeloma by recruitment of death receptors and downstream signaling molecules into lipid rafts. Blood 2007, 109, 711-719. [CrossRef] [PubMed]

35. Gaikwad, A.; Poblenz, A.; Haridas, V.; Zhang, C.; Duvic, M.; Gutterman, J. Triterpenoid electrophiles (avicins) suppress heat shock protein-70 and $\mathrm{x}$-linked inhibitor of apoptosis proteins in malignant cells by activation of ubiquitin machinery: Implications for proapoptotic activity. Clin. Cancer Res. 2005, 11, 1953-1962. [CrossRef] [PubMed]

36. Reis-Sobreiro, M.; Gajate, C.; Mollinedo, F. Involvement of mitochondria and recruitment of Fas/CD95 signaling in lipid rafts in resveratrol-mediated antimyeloma and antileukemia actions. Oncogene 2009, 28, 3221-3234. [CrossRef]

37. Pommier, A.J.; Alves, G.; Viennois, E.; Bernard, S.; Communal, Y.; Sion, B.; Marceau, G.; Damon, C.; Mouzat, K.; Caira, F.; et al. Liver X Receptor activation downregulates AKT survival signaling in lipid rafts and induces apoptosis of prostate cancer cells. Oncogene 2010, 29, 2712-2723. [CrossRef] [PubMed]

38. Bang, B.; Gniadecki, R.; Gajkowska, B. Disruption of lipid rafts causes apoptotic cell death in HaCaT keratinocytes. Exp. Dermatol. 2005, 14, 266-272. [CrossRef]

39. Li, H.Y.; Appelbaum, F.R.; Willman, C.L.; Zager, R.A.; Banker, D.E. Cholesterol-modulating agents kill acute myeloid leukemia cells and sensitize them to therapeutics by blocking adaptive cholesterol responses. Blood 2003, 101, 3628-3634. [CrossRef]

40. Mineo, C.; James, G.L.; Smart, E.J.; Anderson, R.G. Localization of epidermal growth factor-stimulated Ras/Raf-1 interaction to caveolae membrane. J. Biol. Chem. 1996, 271, 11930-11935. [CrossRef]

41. Liu, P.; Ying, Y.; Ko, Y.G.; Anderson, R.G. Localization of platelet-derived growth factor-stimulated phosphorylation cascade to caveolae. J. Biol. Chem. 1996, 271, 10299-10303. [CrossRef]

42. Nel, A.E. T-cell activation through the antigen receptor. Part 1: Signaling components, signaling pathways, and signal integration at the T-cell antigen receptor synapse. J. Allergy Clin. Immunol. 2002, 109, 758-770. [CrossRef] [PubMed]

43. Patel, H.H.; Murray, F.; Insel, P.A. G-protein-coupled receptor-signaling components in membrane raft and caveolae microdomains. In Protein-Protein Interactions as New Drug Targets; Springer: Berlin/Heidelberg, Germany, 2008; pp. 167-184. [CrossRef]

44. Ivanovs, A.; Rybtsov, S.; Anderson, R.A.; Turner, M.L.; Medvinsky, A. Identification of the Niche and Phenotype of the First Human Hematopoietic Stem Cells. Stem Cell Rep. 2014, 2, 449-456. [CrossRef] [PubMed]

45. Wright, D.E.; Wagers, A.J.; Gulati, A.P.; Johnson, F.L.; Weissman, I.L. Physiological Migration of Hematopoietic Stem and Progenitor Cells. Science 2001, 294, 1933-1936. [CrossRef] [PubMed]

46. Abbas, A.K.; Lichtman, A. Cellular and Molecular Immunology, 5th ed.; Saunders: Philadelphia, PA, USA, 2003.

47. Dzierzak, E.; Speck, N.A. Of lineage and legacy: The development of mammalian hematopoietic stem cells. Nat. Immunol. 2008, 9, 129-136. [CrossRef] [PubMed]

48. Medvinsky, A.; Rybtsov, S.; Taoudi, S. Embryonic origin of the adult hematopoietic system: Advances and questions. Development 2011, 138, 1017-1031. [CrossRef] [PubMed] 
49. Lemischka, I.R. Microenvironmental regulation of hematopoietic stem cells. Stem Cells 2009, 15, 63-68. [CrossRef] [PubMed]

50. Sagar, B.M.M.; Rentala, S.; Gopal, P.N.V.; Sharma, S.; Mukhopadhyay, A. Fibronectin and laminin enhance engraftibility of cultured hematopoietic stem cells. Biochem. Biophys. Res. Commun. 2006, 350, 1000-1005. [CrossRef] [PubMed]

51. Ellis, S.J.; Tanentzapf, G. Integrin-mediated adhesion and stem-cell-niche interactions. Cell Tissue Res. 2009, 339, 121. [CrossRef] [PubMed]

52. Kurth, I.; Franke, K.; Pompe, T.; Bornhäuser, M.; Werner, C. Hematopoietic stem and progenitor cells in adhesive microcavities. Integr. Biol. 2009, 1, 427-434. [CrossRef]

53. Barczyk, M.; Carracedo, S.; Gullberg, D. Integrins. Cell Tissue Res. 2009, 339, 269. [CrossRef]

54. Del Pozo, M.A.; Price, L.S.; Alderson, N.B.; Ren, X.-D.; Schwartz, M.A. Adhesion to the extracellular matrix regulates the coupling of the small GTPase Rac to its effector PAK. EMBO J. 2000, 19, 2008-2014. [CrossRef] [PubMed]

55. Del Pozo, M.A.; Kiosses, W.B.; Alderson, N.B.; Meller, N.; Hahn, K.M.; Schwartz, M.A. Integrins regulate GTP-Rac localized effector interactions through dissociation of Rho-GDI. Nat. Cell Biol. 2002, 4, 232. [CrossRef] [PubMed]

56. Krauss, K.; Altevogt, P. Integrin Leukocyte Function-associated Antigen-1-mediated Cell Binding Can Be Activated by Clustering of Membrane Rafts. J. Biol. Chem. 1999, 274, 36921-36927. [CrossRef] [PubMed]

57. Leitinger, B.; Hogg, N. The involvement of lipid rafts in the regulation of integrin function. J. Cell Sci. 2002, 115, 963. [PubMed]

58. Del Pozo, M.A.; Alderson, N.B.; Kiosses, W.B.; Chiang, H.-H.; Anderson, R.G.W.; Schwartz, M.A. Integrins regulate Rac targeting by internalization of membrane domains. Science 2004, 303, 839-842. [CrossRef] [PubMed]

59. Ratajczak, M.Z. A novel view of the adult bone marrow stem cell hierarchy and stem cell trafficking. Leukemia 2015, 29, 776-782. [CrossRef] [PubMed]

60. Lapidot, T.; Kollet, O. The Brain-Bone-Blood Triad: Traffic Lights for Stem-Cell Homing and Mobilization. Hematology 2010, 2010, 1-6. [CrossRef]

61. Bonig, H.; Papayannopoulou, T. Hematopoietic stem cell mobilization: Updated conceptual renditions. Leukemia 2013, 27, 24-31. [CrossRef]

62. Greenbaum, A.M.; Link, D.C. Mechanisms of G-CSF-mediated hematopoietic stem and progenitor mobilization. Leukemia 2011, 25, 211-217. [CrossRef]

63. Adamiak, M.; Poniewierska-Baran, A.; Borkowska, S.; Schneider, G.; Abdelbaset-Ismail, A.; Suszynska, M.; Abdel-Latif, A.; Kucia, M.; Ratajczak, J.; Ratajczak, M.Z. Evidence that a lipolytic enzyme-Hematopoietic-specific phospholipase C- $\beta 2$ - promotes mobilization of hematopoietic stem cells by decreasing their lipid raft-mediated bone marrow retention and increasing the promobilizing effects of granulocytes. Leukemia 2016, 30, 919-928. [CrossRef]

64. Ratajczak, M.Z.; Adamiak, M. Membrane Lipid Rafts, Master Regulators of Hematopoietic Stem Cell Retention in Bone Marrow, and Their Trafficking. Leukemia 2015, 29, 1452. [CrossRef] [PubMed]

65. Shirvaikar, N.; Marquez-Curtis, L.A.; Shaw, A.R.; Turner, A.R.; Janowska-Wieczorek, A. MT1-MMP association with membrane lipid rafts facilitates G-CSF-induced hematopoietic stem/progenitor cell mobilization. Exp. Hematol. 2010, 38, 823-835. [CrossRef] [PubMed]

66. Shirvaikar, N.; Marquez-Curtis, L.A.; Janowska-Wieczorek, A. Hematopoietic Stem Cell Mobilization and Homing after Transplantation: The Role of MMP-2, MMP-9, and MT1-MMP. Biochem. Res. Int. 2012, $2012,11$. [CrossRef] [PubMed]

67. Murphy, G.; Nagase, H. Localizing matrix metalloproteinase activities in the pericellular environment. FEBS J. 2011, 278, 2-15. [CrossRef] [PubMed]

68. Morrison, S.J.; Spradling, A.C. Stem Cells and Niches: Mechanisms That Promote Stem Cell Maintenance throughout Life. Cell 2008, 132, 598-611. [CrossRef]

69. Orford, K.W.; Scadden, D.T. Deconstructing stem cell self-renewal: Genetic insights into cell-cycle regulation. Nat. Rev. Genet. 2008, 9, 115. [CrossRef] [PubMed]

70. Yamazaki, S.; Iwama, A.; Morita, Y.; Eto, K.; Ema, H.; Nakauchi, H. Cytokine Signaling, Lipid Raft Clustering, and HSC Hibernation. Ann. N. Y. Acad. Sci. 2007, 1106, 54-63. [CrossRef] 
71. Yamazaki, S.; Iwama, A.; Takayanagi, S.; Morita, Y.; Eto, K.; Ema, H.; Nakauchi, H. Cytokine signals modulated via lipid rafts mimic niche signals and induce hibernation in hematopoietic stem cells. EMBO J. 2006, 25, 3515-3523. [CrossRef]

72. Seita, J.; Weissman, I.L. Hematopoietic stem cell: Self-renewal versus differentiation. Wiley Interdiscip. Rev. Syst. Biol. Med. 2010, 2, 640-653. [CrossRef]

73. Yamazaki, S.; Iwama, A.; Takayanagi, S.; Eto, K.; Ema, H.; Nakauchi, H. TGF-beta as a candidate bone marrow niche signal to induce hematopoietic stem cell hibernation. Blood 2009, 113, 1250-1256. [CrossRef]

74. Vannini, N.; Roch, A.; Naveiras, O.; Griffa, A.; Kobel, S.; Lutolf, M.P. Identification of in vitro HSC fate regulators by differential lipid raft clustering. Cell Cycle 2012, 11, 1535-1543. [CrossRef] [PubMed]

75. Jahn, T.; Leifheit, E.; Gooch, S.; Sindhu, S.; Weinberg, K. Lipid rafts are required for Kit survival and proliferation signals. Blood 2007, 110, 1739-1747. [CrossRef] [PubMed]

76. Bauer, N.; Wilsch-Bräuninger, M.; Karbanová, J.; Fonseca, A.-V.; Strauss, D.; Freund, D.; Thiele, C.; Huttner, W.B.; Bornhäuser, M.; Corbeil, D. Haematopoietic stem cell differentiation promotes the release of prominin-1/CD133-containing membrane vesicles-A role of the endocytic-exocytic pathway. EMBO Mol. Med. 2011, 3, 398-409. [CrossRef] [PubMed]

77. Weigmann, A.; Corbeil, D.; Hellwig, A.; Huttner, W.B. Prominin, a novel microvilli-specific polytopic membrane protein of the apical surface of epithelial cells, is targeted to plasmalemmal protrusions of non-epithelial cells. Proc. Natl. Acad. Sci. USA 1997, 94, 12425-12430. [CrossRef] [PubMed]

78. Yin, A.H.; Miraglia, S.; Zanjani, E.D.; Almeida-Porada, G.; Ogawa, M.; Leary, A.G.; Olweus, J.; Kearney, J.; Buck, D.W. AC133, a Novel Marker for Human Hematopoietic Stem and Progenitor Cells. Blood 1997, 90, 5002. [PubMed]

79. Miraglia, S.; Godfrey, W.; Yin, A.H.; Atkins, K.; Warnke, R.; Holden, J.T.; Bray, R.A.; Waller, E.K.; Buck, D.W. A Novel Five-Transmembrane Hematopoietic Stem Cell Antigen: Isolation, Characterization, and Molecular Cloning. Blood 1997, 90, 5013.

80. Bhatia, M. AC133 expression in human stem cells. Leukemia 2001, 15, 1685-1688. [CrossRef]

81. Freund, D.; Bauer, N.; Boxberger, S.; Feldmann, S.; Streller, U.; Ehninger, G.; Werner, C.; Bornhäuser, M.; Oswald, J.; Corbeil, D. Polarization of Human Hematopoietic Progenitors During Contact with Multipotent Mesenchymal Stromal Cells: Effects on Proliferation and Clonogenicity. Stem Cells Dev. 2006, 15, 815-829. [CrossRef]

82. Röper, K.; Corbeil, D.; Huttner, W.B. Retention of prominin in microvilli reveals distinct cholesterol-based lipid micro-domains in the apical plasma membrane. Nat. Cell Biol. 2000, 2, 582-592. [CrossRef]

83. Kuçi, S.; Wessels, J.T.; Bühring, H.-J.; Schilbach, K.; Schumm, M.; Seitz, G.; Löffler, J.; Bader, P.; Schlegel, P.G.; Niethammer, D.; et al. Identification of a novel class of human adherent CD34- stem cells that give rise to SCID-repopulating cells. Blood 2003, 101, 869-876. [CrossRef]

84. Arndt, K.; Grinenko, T.; Mende, N.; Reichert, D.; Portz, M.; Ripich, T.; Carmeliet, P.; Corbeil, D.; Waskow, C. $\mathrm{CD} 133$ is a modifier of hematopoietic progenitor frequencies but is dispensable for the maintenance of mouse hematopoietic stem cells. Proc. Natl. Acad. Sci. USA 2013, 110, 5582-5587. [CrossRef] [PubMed]

85. Karbanová, J.; Lorico, A.; Bornhäuser, M.; Corbeil, D.; Fargeas, C.A. Prominin-1/CD133: Lipid Raft Association, Detergent Resistance, and Immunodetection. Stem Cells Transl. Med. 2017, 7, 155-160. [CrossRef] [PubMed]

86. Repa, J.J.; Turley, S.D.; Lobaccaro, J.-M.A.; Medina, J.; Li, L.; Lustig, K.; Shan, B.; Heyman, R.A.; Dietschy, J.M.; Mangelsdorf, D.J. Regulation of Absorption and ABC1-Mediated Efflux of Cholesterol by RXR Heterodimers. Science 2000, 289, 1524-1529. [CrossRef] [PubMed]

87. Klucken, J.; Büchler, C.; Orsó, E.; Kaminski, W.E.; Porsch-Özcürümez, M.; Liebisch, G.; Kapinsky, M.; Diederich, W.; Drobnik, W.; Dean, M. ABCG1 (ABC8), the human homolog of the Drosophila white gene, is a regulator of macrophage cholesterol and phospholipid transport. Proc. Natl. Acad. Sci. USA 2000, 97, 817-822. [CrossRef] [PubMed]

88. Laffitte, B.A.; Repa, J.J.; Joseph, S.B.; Wilpitz, D.C.; Kast, H.R.; Mangelsdorf, D.J.; Tontonoz, P. LXRs control lipid-inducible expression of the apolipoprotein E gene in macrophages and adipocytes. Proc. Natl. Acad. Sci. USA 2001, 98, 507-512. [CrossRef] [PubMed]

89. Gaus, K.; Kritharides, L.; Schmitz, G.; Boettcher, A.; Drobnik, W.; Langmann, T.; Quinn, C.M.; Death, A.; Dean, R.T.; Jessup, W.; et al. Apolipoprotein A-1 interaction with plasma membrane lipid rafts controls cholesterol export from macrophages. FASEB J. 2004, 18, 574-576. [CrossRef] [PubMed] 
90. Murphy, A.J.; Akhtari, M.; Tolani, S.; Pagler, T.; Bijl, N.; Kuo, C.-L.; Wang, M.; Sanson, M.; Abramowicz, S.; Welch, C.; et al. ApoE regulates hematopoietic stem cell proliferation, monocytosis, and monocyte accumulation in atherosclerotic lesions in mice. J. Clin. Investig. 2011, 121, 4138. [CrossRef]

91. Yvan-Charvet, L.; Pagler, T.; Gautier, E.L.; Avagyan, S.; Siry, R.L.; Han, S.; Welch, C.L.; Wang, N.; Randolph, G.J.; Snoeck, H.W.; et al. ATP-Binding Cassette Transporters and HDL Suppress Hematopoietic Stem Cell Proliferation. Science 2010, 328, 1689-1693. [CrossRef]

92. Takehara, M.; Takagishi, T.; Seike, S.; Oishi, K.; Fujihara, Y.; Miyamoto, K.; Kobayashi, K.; Nagahama, M. Clostridium perfringens $\alpha$-Toxin Impairs Lipid Raft Integrity in Neutrophils. Biol. Pharm. Bull. 2016, 39, 1694-1700. [CrossRef]

93. Jiang, J.; Kao, C.-Y.; Papoutsakis, E.T. How do megakaryocytic microparticles target and deliver cargo to alter the fate of hematopoietic stem cells? J. Control. Release 2017, 247, 1-18. [CrossRef]

(C) 2019 by the authors. Licensee MDPI, Basel, Switzerland. This article is an open access article distributed under the terms and conditions of the Creative Commons Attribution (CC BY) license (http://creativecommons.org/licenses/by/4.0/). 